\title{
PAMIĘĆ GUŁagu CZY PAMIĘĆ O GUŁagu? ZUZANNA BOGUMIt, PAMIĘĆ GUŁagu
}

Marta Karkowska

Instytut Filozofii i Socjologii PAN

Liczne opracowania, zbiory dokumentów czy wspomnienia dotyczące obozów pracy w ZSRR, nazywanych GUŁagiem, najczęściej mają na celu przedstawienie samego systemu łagrów powstałych niedługo po rewolucji październikowej w Rosji i ukazanie losów ludzi, przymuszanych do wycieńczającej, niewolniczej pracy. Ten obraz i ta konwencja, znane w Polsce przede wszystkim z ksiązek, takich jak Archipelag GUŁag Aleksandra Sołżenicyna (Sołżenicyn 1981), Inny świat Gustawa Herlinga-Grudzińskiego (Herling-Grudziński 1953) czy opracowanie Anne Applebaum pt. Gułag (Applebaum 2005), powoli przestaja jednak wystarczać. Upływający czas, powolne odchodzenie świadków historii - dawnych więźniów obozów sowieckich - a także skutki zmiany ustrojowej i związane z nimi zmiany sposobu postrzegania instytucji państwa radzieckiego sprawiaja, że konieczne okazuje się podjęcie zupełnie nowych kwestii.

Bez watpienia jedna z nich jest sama pamięć o łagiernej przeszłości pamięć nie tylko więźniów, ich strażników czy współtwórców GUŁagu, ale też ludzi, którzy choć często formalnie nigdy nie byli bezpośrednio związani z tym systemem, to zostali nim naznaczeni. Tę problematykę porusza właśnie książka Zuzanny Bogumił Pamię́ GUŁagu.

Celem publikacji bynajmniej nie jest sama dokumentacja zbrodniczego systemu obozów sowieckich czy analiza mechanizmów jego funkcjonowania. Nie jest nim nawet analiza wspomnień więźniów GULagu - zeków. Przeciwnie, Autorka wielokrotnie podkreśla, iż na całe zagadnienie patrzy z własnej perspektywy - perspektywy badacza przybywającego na tereny dawnych obozów na początku XXI wieku i skupiającego uwagę na procesie odkrywania łagiernej przeszłości przez mieszkańców byłego ZSRR. Już na początku wyraźnie zaznacza, że jej dążeniem nie 
będzie „rozważenie, na ile to, co się pamięta, jest zgodne z tym, co się wydarzyło" (Bogumił 2012: 10). Wskazując różnice między pamięcia jako zjawiskiem społecznym i historia jako nauka, zaznacza, iż interesuje ja pierwsza perspektywa. To właśnie w jej świetle dalej podejmuje kwestie związane z formowaniem się pamięci o GULagu, z procesami, jakie temu towarzyszą.

Przyjęcie takiego założenia, a także ukazanie podstaw metodologicznych badań (mieszczących się w ramach jakościowych badań terenowych, na co wskazuje tzw. etnograficzny warsztat pracy jako podstawa działań) wyznaczają kierunek dalszych analiz. Analizy te opierają się głównie na materiałach zgromadzonych w trakcie wypraw do czterech regionów dzisiejszej Rosji - na Wyspy Sołowieckie, do Republiki Komi, regionu permskiego i na Kołymę. Taki dobór miejsc Autorka uzasadnia „odmiennościa problemów i znaczeń” łagiernej przeszłości, wielością sposobów radzenia sobie z tą przeszłością w dzisiejszej Rosji i chęcią ukazania tej różnorodności (tamże: 44). Bez wątpienia przyjęcie takiego założenia okazało się słuszne, choćby ze względu na to, jak liczne i rozproszone w granicach całego państwa były obozy GUŁagu, w jak różnych warunkach funkcjonowały i jak różny miały charakter. Szkoda jedynie, iż w swojej książce Autorka nie wskazała jasno (być może uznając to za rzecz oczywista), jak wiele miejsc i regionów musiała pominaćc. Taka uwaga z pewnością pomogłaby mniej zorientowanemu w temacie czytelnikowi dostrzec, jak wiele jeszcze (poza prezentowanymi przykładami) można byłoby odkryć sposobów wspominania i radzenia sobie z trudną przeszłościa, jak unikatowym doświadczeniem jest to opisywane w omawianej tu pracy.

Bez watepienia zaletą pracy jest bogactwo i różnorodność przywoływanych materiałów. Zuzanna Bogumił odnosi się do opisanych przez świadków rytuałów, ich interpretacji znaków pamięci (krzyży, tablic pamiątkowych), ale też do tworzących przestrzeń pamięci pomników, wystaw muzealnych, cmentarzy. Prezentuje działania różnych aktorów pamięci (jak określeni zostaja w książce ludzie, instytucje czy organizacje, takie jak muzea, Cerkiew prawosławna czy organizacja pozarządowa Stowarzyszenie Memoriał ${ }^{1}$ ); a nawet odwołuje się do materiałów archiwalnych i cytuje wypowiedzi zwykłych mieszkańców poszczególnych regionów. Stara się przy tym nie tylko opisać, ale też zinterpretować różne sposoby wspominania i upamiętniania łagiernej przeszłości. Poczynione obserwacje,

\footnotetext{
${ }^{1}$ Stowarzyszenie Memoriał to międzynarodowa organizacja powstała w 1989 roku, której celem sa badania historyczne i propagowanie wiedzy o ofiarach represji radzieckich (zwłaszcza okresu stalinowskiego), a także ochrona praw człowieka w krajach byłego ZSRR.
} 
rozmowy i zebrane materiały są dla niej punktem wyjścia do wskazania nie tylko podobieństw, ale też odmienności pamięci o GUŁagu w różnych częściach dawnego Związku Radzieckiego.

Jedną z największych zalet pracy nie jest jednak tylko porównanie i analiza samej pamięci o sowieckich obozach pracy czy wskazanie na wielość postaw mieszkańców dzisiejszej Rosji wobec tego zbiorowego doświadczenia. Równie ważne jest ukazanie przez Autorkę odmienności w sposobach postrzegania łagiernej przeszłości przez Rosjan i osoby przybyłe spoza granic Federacji. Jak istotne jest to zagadnienie, pokazuje zamieszczona na samym początku książki historia grupy niemieckiej młodzieży, która lato 2007 roku spędziła przy renowacji łagru Perm-36. Młodzi Niemcy, postrzegający łagry przez analogie do zbrodni popełnianych przez III Rzeszę i oczekujący rozliczeń z przeszłością, ukazani są tu w sytuacji konieczności zmierzenia się z akceptacją, a nawet szacunkiem, jakim otaczani są niektórzy dawni strażnicy łagrów, obecnie pracujący w łagiernym muzeum. Choć to doświadczenie do końca pozostaje niezrozumiałe dla nich samych, dla Autorki jest punktem wyjścia do rozważań nad odmiennością, a niekiedy wręcz nieprzekładalnościa perspektyw i doświadczeń ludzi ukształtowanych przez różne kultury. Do tego tematu powraca zresztą wielokrotnie, porównując i wskazując na różnice pamięci oraz stosunku do przeszłości ludzi ukształtowanych przez rosyjską i zachodnioeuropejską kulturę. Jednocześnie wielokrotnie odwołuje się do własnych doświadczeń, zestawiając np. rytuały towarzyszące uroczystościom organizowanym przez Stowarzyszenie Memoriał i te będące częścią polskich pielgrzymek do Częstochowy.

O specyfice ujęcia tematyki pamięci świadczy też sposób prezentacji zebranego materiału, przeprowadzonych analiz i wniosków. Analityczna część książki rozpoczyna rozdział dotyczący Wysp Sołowieckich, których historia często łączona jest z początkami GULagu jako systemu represji. Nie to jednak jest głównym przedmiotem rozważań, lecz analiza zasadniczej zmiany w sposobie postrzegania łagrów i więzionych w nich zeków, jaka dokonała się na przełomie lat osiemdziesiątych i dziewięćdziesiątych XX wieku. Przyjęcie takiego punktu wyjścia pozwala na wskazanie kontekstu, w jakim rozpoczęło się tworzenie nowego języka, nowych rytuałów czy samego myślenia o przeszłości.

Autorka w tym miejscu dokładnie wyjaśnia, wielokrotnie później przywoływane, pojęcie „karnawału pamięci” Padraica Kenneya (tamże: 24)².

\footnotetext{
${ }^{2}$ Przywołując pojęcie „karnawał pamięci”, Autorka przedstawia zarówno interpretację jego twórcy (Padraica Kenneya), jak i własna.
} 
Pojęcie to, oznaczające dla niej zapoczątkowany zmianami politycznymi końca lat osiemdziesiatych okres rozbudzenia pamięci o GUŁagu, jest podstawą i jednocześnie inspiracją do rozważań nad różnymi projektami pamięci: muzealnym, prawosławnym i „memorialnym” - czyli promowanym przez Stowarzyszenie Memoriał. Wszystkie traktowane są tu jako różne sposoby upamiętniania tej samej przeszłości przez różnych aktorów, aktorów mających różne cele, priorytety i możliwości. Odwołując się do sytuacji z początku nowego tysiąclecia, Autorka wskazuje też, że przeszłość, nawet taka jak ta związana z doświadczeniem GUŁagu, niekoniecznie musi mieć siłę spajającą i silnie oddziaływać na tworzenie się poczucia wspólnoty. Po okresie karnawału pamięci następuje bowiem proza dnia codziennego, a wielość projektów pamięci niekoniecznie musi przełożyć się na wzrost zainteresowania współczesną historią wśród mieszkańców regionu czy szybkie wykrystalizowanie się jednej, dominującej wizji przeszłości. Jak ujęła to jedna z pracownic muzeum na Wyspach Sołowieckich, tu „każdy ma własne Sołowki” (tamże: 155).

Kolejny rozdział dotyczy pamięci o łagrach sowieckich w Republice Komi. Ten przykład jest podstawą do rozważań nad różnorodnością form, w jakich przejawiać się może pamięć: pomników, cmentarzy, wystaw muzealnych. Szczególnie interesujące sa tu analizy dotyczące łączenia wcześniejszych, ukształtowanych w czasach Związku Radzieckiego wizji łagrów i nowych treści, i interpretacji, jakie pojawiły się w momencie rozpoczęcia zmian systemu politycznego - po 1989 roku. Sposób, w jaki radzono sobie z nowo odkrytymi fragmentami przeszłości, faktami związanymi z przybyciem i warunkami życia zeków (więźniów GUŁagu) ilustrują najważniejsze zmiany i procesy, jakim została poddana pamięć lokalnych wspólnot.

Rozdział dotyczący regionu perskiego ma już inny charakter - dominuje tu chęć ukazania projektów promowanych przez dwóch różnych aktorów pamięci - Stowarzyszenie Memoriał i Muzeum Perm-36. Choć oba projekty opierają się na propozycji stworzenia muzeum, funkcje nowej instytucji, jej kształt, formy i zastosowane treści przekazu zasadniczo się od siebie różnią, co jasno pokazują analizy Autorki Pamięci GUŁagu. To zestawienie okazuje się bardzo cenne - ujawnia bowiem, w jak różny sposób kształtowana może być pamięć, jak istotny okazuje się nie tylko sam akt upamiętnienia, ale też znaczenia, jakie niesie ze sobą, dobór treści, sposób interpretacji i cele, jakie mu towarzyszą.

Ostatni rozdział ma na celu opisanie pamięci o GUłagu na Kołymie, a dokładniej tworzenia się nowej tożsamości mieszkańców regionu uważanego za stolicę „Archipelagu”. Autorka przywołuje tu różne przykłady 
upamiętnień, wskazując na - dostrzeganą także przez samych mieszkańców Kołymy - wielowymiarowość upamiętnianych postaci czy wydarzeń, niepozwalającą na ich zdecydowaną i jednoznaczną ocenę. Wiele miejsca poświęca wystawom czy pomnikom, zwłaszcza tak unikatowym jak memorialny kompleks Maska Bólu w Magadanie (będącej jedyną formą świeckiego i artystycznego upamiętnienia ofiar GULagu), ale też odbiór przedstawień, takich jak monument upamiętniający Edwarda Berzina - postać kontrowersyjną, a jednak cieszącą się szacunkiem także wśród wspólczesnych mieszkańców miasta.

Przedstawione przykłady różnych projektów i sposobów upamiętniania przeszłości w różnych regionach Federacji Rosyjskiej są podstawą do sformułowania wniosków dotyczących specyfiki pamiętania i wspominania GULagu w Federacji Rosyjskiej. W Zakończeniu Autorka skupia się na wskazaniu podobieństw i różnic aktów wspominania oraz sposobów upamiętniania, obserwowanych $\mathrm{w}$ różnych regionach dawnego Związu Radzieckiego. Podkreśla, iż zapoczątkowany pod koniec lat osiemdziesiątych „karnawałem pamięci” proces formowania pamięci o GULagu, choć obecnie już nie tak intensywny i szybki jak jeszcze dwadzieścia lat temu, nie może być uznany za zakończony. Jego wynikiem jest zaś to, że o ile Cerkwi wspieranej przez państwo „udało się wytworzyć spójny prawosławny język interpretacji doświadczenia GUŁagu... o tyle Memoriałowi nie udało się wypracować spójnego, świeckiego języka" (Bogumił 2012: 327 -328). Pomimo iż przedstawione wyjaśnienia tego stanu rzeczy można uznać za przekonujące, to zaprezentowana teza wywołuje kolejne pytania. Najważniejsze, jakie nasuwaja się w tym momencie, dotyczą tego, czy podział opierający się na wyróżnieniu sfery „świeckiej” i „religijnej” pamięci o GUŁagu oddaje całą specyfikę rosyjskiego wspominania łagiernej przeszłości? Czy nie warto byłoby bliżej przyjrzeć się także innym kwestiom, jak choćby odmienności pamięci kształtowanej przez państwo i jego instytucje oraz pamięci promowanej przez instytucje pozarządowe, niezależne?

Te pytania pozostają istotne także $\mathrm{z}$ innego powodu. Odwołując się do własnych analiz i obserwacji, Autorka zwraca też uwagę na to, iż z pozoru podobne znaki pamięci, sposoby upamiętniania, w wymiarze lokalnym w interpretacji różnych aktorów pamięci mogą zyskiwać zupełnie odmienne znaczenia i być bardzo różnie postrzegane przez lokalne wspólnoty. To bardzo ważny wniosek, gdyż pokazuje, jak różne, często wręcz sprzeczne, moga być wizje przeszłości na poziomie lokalnym i narodowym lub państwowym. Warto byłoby go bardziej uwypuklić. 
Pamięć o radzieckich obozach pracy w dzisiejszej Rosji przedstawiona przez Zuzannę Bogumił jest pamięcią niespójna, wciąż „przepracowywaną", często też fragmentaryczną i wybiórczą, niosąca ze sobą różne emocje i znaczenia na poziomie lokalnym, a jednocześnie zyskującą status coraz ważniejszego elementu współczesnego, rosyjskiego dziedzictwa kulturowego. Właśnie ukazanie tych cech pamięci o GUŁagu, rozpatrywanych na różnych poziomach, należy uznać za najważniejszą zaletę całej pracy.

Tu warto zwrócić uwagę na jeszcze jedno zagadnienie. Autorka na kartach książki przynajmniej kilkakrotnie (mniej lub bardziej jednoznacznie) ubolewa, iż nie mogła być obecna w odwiedzonych przez siebie miejscach pod koniec lat osiemdziesiatych, gdy rozpoczynał się „,karnawał pamięci” i gdy „Historia GULagu została odkopana z niepamięci i wylała się na powierzchnię w całej swojej niezrozumiałości” (tamże: 317). Moment, gdy udało się jej dotrzeć do dawnych miejsc represji - pierwsze lata nowego tysiąclecia - uznaje za czas, gdy ta pierwsza ważna faza procesu pamięci już się zakończyła i gdy codzienne problemy przesłoniły wcześniejszą nieodpartą potrzebę wspominania. To czasowe przesunięcie okazało się jednak bardzo cenne. Dało mianowicie możliwość spojrzenia już z pewnego dystansu na proces zapoczątkowany ponad dwadzieścia lat temu, szansę przyjrzenia się jego dynamice i wskazania jego bardziej i mniej trwałych skutków. Pozwoliło również na wytypowanie najważniejszych elementów tego procesu i - co nie mniej ważne - różnych możliwości interpretacji pamięci o łagiernej przeszłości wybranych regionów.

Jeszcze jedną kwestia, na którą warto zwrócić uwagę przy lekturze całej pracy, jest jej historyczna wartość. Książka z pewnością może rozczarować historyków szukających w niej odwołań do nieznanych dokumentów, spodziewających się przedstawienia wyników kwerend w archiwach. Choć Autorka wspomina o takich dokumentach - jak choćby o odnalezionych przypadkowo listach więźniów GUŁagu - nie analizuje ich treści, a jedynie reakcje na ich odkrycie. Także przytoczonych opisów, opowieści czy szczodrze przywoływanych wypowiedzi ważnych aktorów pamięci nie można traktować jako pełnoprawnych źródeł historycznych do dziejów GUŁagu, których wiarygodność można sprawdzić, posługując się klasyczną, rzetelną krytyką źródła. Dzieje się tak nie ze względu na brak możliwości porównań, a niekiedy sprzeczność różnych przekazów czy mistyczne przesłania, jakie zawieraja (jak choćby opowieść o ojcu, który we śnie powiedział córce, iż pochowano go przy drodze), ale przede wszystkim dlatego, iż dotyczą one nie samego GUŁagu, a wspomnień o nim; nie pamięci z̨eków, a pamięci o žkach i ich losach. Książka Zuzanny Bogumił nie jest więc - wbrew 
tytułowi - książką o pamięci twórców, ofiar czy obserwatorów GUŁagu, ale książką o pamięci o GULagu, kształtującej się już po zamknięciu ostatniego obozu i zmianie systemowej - zmianie, która pozwoliła tę pamięć przenieść ze sfery prywatnej w sferę publiczną. Tak też należy ją odczytywać.

Czytelnik pragnący przede wszystkim odnaleźć potwierdzenia faktów historycznych $\mathrm{w}$ przytaczanych zapisach pamięci może poczuć się rozczarowany. Takich potwierdzeń znajdzie niewiele. Odkryje raczej przykłady pracy pamięci na rzecz ujawnienia zatajonej przeszłości i dowody na jej współpracę w odkrywaniu prawd zawartych we wciąż niedostępnych archiwaliach.

W tym miejscu warto podjąc jeszcze jedną kwestię, a mianowicie rolę przywoływanych koncepcji teoretycznych, modeli interpretacyjnych. Choć Autorka już na pierwszych stronach jako kluczowe dla swoich analiz przedstawia założenia teoretyczne, takie jak propozycje przedstawicieli szkoły tartusko-moskiewskiej Borysa Uspienskiego i Jurija Lotmana, koncepcje przeciw-historii Michaela Foucaulta, a także odwołuje się do pojęć wprowadzonych przez Maurice'a Halbwachsa, Jana Assmanna, Pierre'a Nora; w dalszych rozdziałach traktuje je przede wszystkim jako inspirację. Opisując i analizując wystawy, pomniki czy cmentarze, rzadko do nich szerzej nawiązuje, często jedynie sygnalizując skojarzenia ze zjawiskami ujętymi w ramy przywołanych wcześniej konstrukcji teoretycznych. Dopiero w Zakończ̨eniu więcej miejsca poświęca przedstawieniu wniosków $\mathrm{z}$ przeprowadzonych analiz w odniesieniu do przywoływanych koncepcji teoretycznych. Tu jednak stosuje je głównie do ogólnej charakterystyki pamięci o GUŁagu mieszkańców Federacji Rosyjskiej, roli np. Cerkwi prawosławnej $\mathrm{w}$ konstruowaniu pamięci o obozach pracy w ZSRR czy celów dyskursu przeciw-historii zaproponowanego przez Stowarzyszenie Memoriał. Taki sposób wykorzystania podstaw teoretycznych pracy wobec obfitości zgromadzonych materiałów pozostawia jednak poczucie niedosytu. Lektura całości pracy wywołuje chęć poznania możliwości, jakie niesie ze sobą zastosowanie przywoływanych koncepcji także na poziomie regionu i w odniesieniu do pamięci wspólnot lokalnych. Jest to istotne tym bardziej, że autorka wielokrotnie odwołuje się nie tylko do wypowiedzi czy poglądów głoszonych przez członków Memoriału, muzealników czy innych ważnych aktorów pamięci, lecz także „zwykłych ludzi”, podejmuje zagadnienie tworzenia się wspólnot lokalnych właśnie na podwalinach wspólnie wypracowanej pamięci.

Należy tu zaznaczyć, iż oddanie głosu także im - często przypadkowym, dzisiejszym mieszkańcom poszczególnych regionów, wskazanie na ich reakcje i przedstawienie ich sposobu odbioru łagrów sowieckich i ich 
historii bez wątpienia jest jednym z cenniejszych elementów całej pracy. Równie wartościowe okazują się zdjęcia zamieszczone na końcu książki, nie tylko ilustrujące prowadzone w pracy analizy, ale też stanowiące dla czytelnika źródło wiedzy o sposobie, w jaki traktowane są różne projekty pamięci. Kwiaty składane przy pomnikach, zawieszone na drzewach chusty, złożone pokarmy, w innym zaś miejscu zarośnięte i trudno dostępne monumenty dużo więcej i bardziej przekonująco mówią o stosunku do tych form upamiętnienia, niż wynikałoby to z nawet najbardziej szczegółowych relacji.

Kilka słów trzeba także poświęcić samej konstrukcji książki. Jej lektura nie jest łatwa nie tylko ze względu na wielość przykładów, wielowątkowość i wieloaspektowość całego zagadnienia. Wiele informacji, ważnych dla zrozumienia całości tekstu - zwłaszcza przez mniej zorientowanych czytelników - znaleźć można w niekiedy bardzo obszernych przypisach, charakterystycznych dla warsztatu etnograficznego. Dlatego zapoznając się z tą publikacją, należy zwrócić uwagę także na te wydzielone z głównego tekstu fragmenty. Nierzadko zawierają one odpowiedzi na pytania nasuwające się w trakcie zapoznawania się z zawartością tej publikacji.

Podsumowując lekturę pracy Zuzanny Bogumił, bez wateienia można stwierdzić, iż Autorka osiagnęła cele stawiane sobie na początku. Dotyczy to zwłaszcza ustalenia funkcji i znaczeń przypisywanym poszczególnym miejscom związanym z historią GUŁagu już nie tylko przez samych zekón i ich strażników, ale też kolejne pokolenia żyjące na terenach dawnych łagrów. Pozostaje jedynie mieć nadzieję, że ten opis i towarzysząca mu analiza procesu kreowania pamięci o radzieckich obozach pracy będą miały kontynuację. Pozwoliłoby to poznać dalsze, zapewne skomplikowane, wielowymiarowe i różnorodne procesy, jakim podlega i będzie podlegać pamięć opisana przez Zuzannę Bogumił. Będzie to już z pewnością nie „pamięć GUŁagu”, ale „pamięć o GUŁagu”.

Bibliografia:

/// Applebaum A. 2005. Gułag, Świat Książki, Warszawa.

/// Bogumił Z. 2012. Pamięć GUŁagu, Universitas, Kraków.

/// Herling-Grudziński G. 1953. Inny swiat: rapiski sowieckie, Gryf Publications, Londyn.

/// Sołżenicyn A. 1981. Archipelag GUŁag: 1918-1956: próba analizy, tłum.

M. Kaniowski [pseud. Cz.], TON, Toruń. 